\title{
PURSUIT OF INCLUSIVE EDUCATION: INCLUSION OF TEACHERS IN INCLUSIVE EDUCATION
}

\author{
Ingrida Baranauskienè \\ Klaipeda University, Lithuania \\ Diana Saveikienè \\ Klaipeda University, Lithuania
}

\begin{abstract}
By focusing on teachers' approach, the article analyses one of the most relevant issues of today's realities of education - the inclusive education. The following is an important task for politicians for education, school leaders, teachers and greatly affects and influences the life of families with children with disabilities. Object of the research: inclusion of teachers in inclusive education. Aim of the research: to examine aspects of teachers' inclusion in inclusive education by implementing the statistical analysis according to The Teachers' Attitudes Toward Inclusion Scale (TATIS) survey (Gregory, Noto, Cullen, 2010). This study adopted a descriptive survey research design, with 105 teachers as participants from selected secondary schools in Klaipeda city and Klaipeda district, Lithuania. Research results: A study has been conducted demonstrating that the attitudes of educators participating in the study to inclusive education of pupils with a disability are basically positive. The analysis of the research data received allow the teachers are not sufficiently prepared to provide assistance to their students with orientation towards the inclusive training tasks. Teachers who participated in the study agree that all school classes should be rebuilt to meet the needs of students with disabilities and that students with disabilities should be taught in a general education school in an equal educational environment with peers without disabilities. The differences between teachers' attitudes to the inclusive education model and the type of pedagogical school were statistically significant. More than just a gymnasium teacher, either a progymnist or a primary school teacher, fully agrees that the model of inclusive education ensures a more effective transition of pupils with disabilities from special education to general education schools.
\end{abstract}

Keywords: disabilities, inclusive education, teacher, teacher attitudes toward the inclusion.

\section{Introduction}

Attitudes about inclusion are extremely complex and vary from teacher to teacher and school to school. This article explores the attitudes of teachers about inclusion of special needs children in their secondary schools in general education. Relevance is based on the fact that with the adoption and ratification of the United Nations Convention on the Rights of Persons with Disabilities in 2006, Lithuania assumed responsibility to promote, protect and ensure the full and equal enjoyment of all human rights and fundamental freedoms by all persons 
with disabilities, and to promote respect for their inherent dignity. Article 24 states that countries, Parties of the following Convention, shall ensure the right of persons to appropriate education at all levels and lifelong learning directed to the full development of human potential and sense of dignity and self-worth, and the strengthening of respect for human rights, fundamental freedoms and human diversity; development by persons with disabilities of their personality, talents and creativity, as well as their mental and physical abilities, to their fullest potential; enabling persons with disabilities to participate effectively in a free society. The United Nations Convention on the Rights of Persons with Disabilities (2006) priorities the inclusive education of persons with special educational needs and the provision of the necessary support in the general educational system while studying together with peers. In the context of such international policy, there is a need to analyse and rethink the implemented policy and practice of organizing education for persons with special educational needs, practice of education/teaching and the quality of provided educational services in schools for pupils with special educational needs, as well as the new possible role of such institutions.

Object of the research: inclusion of teachers in inclusive education.

Aim of the research: to examine aspects of teachers' inclusion in inclusive education by implementing the statistical analysis according to The Teachers' Attitudes Toward Inclusion Scale (TATIS) survey (Gregory, Noto, Cullen, 2010). This study adopted a descriptive survey research design, with 105 teachers as participants from selected secondary schools in Klaipeda city and Klaipeda district, Lithuania.

Reseatch methods: Quantitative Data Analysis with SPSS.

\section{Theoretical approaches of the research}

Inclusive education has become a prominent international ideal and value in educational policies and practices. It is a seemingly simple concept about opportunities, equality, and solidarity that has wide global appeal. However, inclusion as applied to education connects with various social and political values that have been contested over many decades (Norwich \& Koutsouris, 2017). Successful implementation of inclusive practices depends mainly on teachers' attitudes towards children with special needs and their inclusion, and teachers' willingness to work with children with special needs in their classrooms (Rakap, Cig, \& Parlak-Rakap, 2017).

The literature highlights notion of inclusive education, one that goes beyond an educational policy that aims to secure space for children to have access to education regarding their needs and abilities (Kozleski \& Thorius, 2014; Sailor, 2016; Stepaniuk, 2018). Florian (2015) supports the idea of inclusive pedagogy 
as a transformative approach to individual differences and highlights that inclusive education has the potential to reduce educational inequalities and contribute to democracy by abolishing organisational and educational practices that are based on bell curve distributions that result in or sustain disproportionality (Florian, 2015).

Education can help change society by improving and strengthening skills, values, communications, mobility (link with personal opportunity and prosperity), personal prosperity and freedom. In the short term, however, education usually reflects society rather strongly: the values and attitudes that inform it are those of society at large. The Salamanca Statement, adopted by UNESCO in July 1994, was adopted by 92 governments and 25 non-government organisations:

- Every child has a fundamental right to education and must be given the opportunity to achieve and maintain acceptable levels of learning.

- $\quad$ Every child has unique characteristics, interests, abilities and learning needs.

- $\quad$ Education systems should be designed and educational programmes implemented to take into account the wide diversity of these characteristics and needs.

- Those with special educational needs must have access to mainstream schools, which should accommodate them with a child-centred pedagogy capable of meeting those needs.

- Mainstream schools with this inclusive orientation are the most effective means of combating discriminatory attitudes, creating welcoming communities, building an inclusive society and achieving education for all. Moreover, they provide an effective education for the majority of children (without special needs) and improving the efficiency and ultimately the cost effectiveness of the entire education system.

Teacher attitudes toward the inclusion of children with disabilities into general education classrooms have been found to be strong predictors of the success of efforts to create inclusive learning communities. Specifically, research has shown that when teachers have positive mindsets toward inclusion, they more readily adapt their teaching methods to meet a variety of student learning needs (Cullen, Gregory, \& Noto, 2010). Slightly more than a decade later, Loreman, Earle, Sharma and Forlin sought to distill several other attitudinal scales into an improved scale measuring pre-service teacher attitudes toward inclusive education. In their 2007 study, Loreman et al. developed the Sentiments, Attitudes, and Concerns about Inclusive Education scale (SACIE) using five factor themes: 1) workload and stress, 2) resources, 3) time, training, competence, 4) other student relationships, and 5) academic impact on rest of class (p. 156). 
Baranauskiene \& Saveikiene, 2018. Pursuit of Inclusive Education: Inclusion of Teachers in Inclusive Education

Specifically, a tool was needed that would measure teacher attitudes toward the inclusion of children with disabilities. The review of the literature revealed this subject to have three key dimensions:

a) Affective: Perceptions of students with disabilities (POS),

b) Cognitive: Perceptions of professional roles and functions (PRF),

c) Conative: Beliefs about the efficacy of inclusion (BEI).

There was no existing instrument found that measured all three dimensions (Cullen, Gregory, \& Noto, 2010).

\section{Methods of the empirical research}

When preparing the TATIS scale, authors emphasize one of the key principles of its formulation: the problem is that education policies, various strategies and reform initiatives can not guarantee the successful inclusion of pupils with disabilities in the general education classes, as factors of teachers' attitudes are crucial for the successful implementation of the following process: effective management and administration support, sufficient funding, effective implementation systems, availability of evidence-based supportive services, participation of interested parties, adequate opportunities for occupational development for teachers and other staff. The author's analysis attaches great importance to the attitudes and convictions of teachers themselves, as according to the authors of the scale, when teachers have a positive attitude towards the engagement/inclusion, they are more willing to adapt and change their teaching methods in order to satisfy the diversity of learning needs of all pupils.

TATIS was created in accordance with two important purified attitudes of the scale makers:

1) The success of efforts to create inclusive learning communities depends heavily upon the effectiveness of methods for engendering positive teacher attitudes and beliefs toward inclusion;

2) Due to shifts in educational policy, there have been dramatic changes in special education concepts, terminology, and teaching pedagogy in the past 8 years. The former observation indicated that there is a need for research on how best to assist teachers in the formation of positive attitudes and beliefs toward inclusion.

\section{Research sample and ethics}

The quantitative research included $105(\mathrm{~N}=105)$ participants, working in schools of the Klaipeda city and Klaipeda district. School teachers were selected at random, focusing on the fact that teachers' workplace would be in general education rather than in a special school. 
The survey followed the general principles of ethical research, which are closely linked to the reliability of the analysis and presentation of empirical data, avoiding distortion of facts. The survey also followed the ethics of research participants - teachers. Participants were informed about the aims of the research, methods of data collection, usage of data for scientific purposes and assurance of confidentiality of personal information.

\section{Sociodemographic characteristics of the subjects}

The research involved 105 teachers, 84.8 per cent of women and 15.2 per cent of men. The majority of teachers represented a progymnasium (35.2 per cent), slightly less a gymnasium (34.3 per cent) and a primary school (30.5 per cent).

By applying the Pearson correlation coefficient, a strong and statistically reliable relationship was found between the age and job tenure of teachers who participated in the study $(\mathrm{r}=0.864, \mathrm{p}=0.000)$. Accordingly, the older the teachers, the longer is their job tenure.

In order to be able to identify the differences between the attitudes of teachers towards inclusive education, teachers of the research have been divided into 3 age groups according to their age and job tenure. The percentages are 35.2 per cent for the 26-35 year-old age group, 33.3 per cent for the 36-46 year-old group and 31.4 per cent of teachers for the older than 47 year-old age group. 35.2 per cent of teachers had a job tenure of 2-8 years, 30.5 per cent $-9-18$ years and 34.3 per cent of teachers had a job tenure of more than 20 years.

Most of respondents were senior teachers (40 per cent), almost one-third (34.3 per cent) were teachers and one-quarter (25.7) were teachersmethodologists. Only a small part of teachers, who participated in the research, have a bachelor's degree received in a college (6.7 per cent), nearly three-quarter (76.2 per cent) - a bachelor's degree received in a university, and almost one-fifth (17.1 per cent) have a master's degree.

In order to determine whether the attitudes of teachers working in a progymnasium, primary school and gymnasium towards inclusive education are different, a Chi-Square criterion was applied. Statistically significant differences in the attitudes of teachers towards one statement were identified $\left(\chi^{2}=25,740\right.$, $\mathrm{df}=4, \mathrm{p}=0,000$, presented in Table 1$)$.

Nearly two-thirds (66.7 per cent) of gymnasium teachers, less than half (40.5) progymnasium teachers and a small part (15.6) of primary school teachers fully agree that the model of inclusive education ensures an effective transfer of pupils with disabilities from special education institutions to general education schools. 
Baranauskiene \& Saveikiene, 2018. Pursuit of Inclusive Education: Inclusion of Teachers in Inclusive Education

Table 1 Differences in the attitudes of teachers towards the model of inclusive education that ensures an effective transfer of pupils with disabilities from special education institutions to general education schools according to the type of school

\begin{tabular}{|c|c|c|c|c|c|}
\hline \multirow[t]{2}{*}{ Proposition } & \multirow[t]{2}{*}{ Agreement } & \multicolumn{3}{|c|}{ School type } & \multirow{2}{*}{ In all } \\
\hline & & Progymnasium & $\begin{array}{c}\text { Primary } \\
\text { school }\end{array}$ & Gymnasium & \\
\hline \multirow{3}{*}{$\begin{array}{l}\text { Inclusion is a more } \\
\text { efficient model for } \\
\text { educating students } \\
\text { with mild to } \\
\text { moderate } \\
\text { disabilities because } \\
\text { it reduces transition } \\
\text { time (i.e., the time } \\
\text { required to move } \\
\text { from one setting to } \\
\text { another). }\end{array}$} & $\begin{array}{l}\text { Neither } \\
\text { Agree nor } \\
\text { Disagree }\end{array}$ & $18,9 \%$ & $40,6 \%$ & $0 \%$ & $19,0 \%$ \\
\hline & Agree & $40,5 \%$ & $43,8 \%$ & $33,3 \%$ & $39,0 \%$ \\
\hline & $\begin{array}{l}\text { Strongly } \\
\text { Agree }\end{array}$ & $40,5 \%$ & $15,6 \%$ & $66,7 \%$ & $41,9 \%$ \\
\hline
\end{tabular}

The Mann-Whitney $\mathbf{U}$ criterion was applied to determine the difference between the attitudes of the instructor and the gymnasium to inclusive education (presented in Table 2).

Gymnasium teachers more than progymnasium teachers agree that the model of inclusive education ensures a more effective transfer of pupils with disabilities from special education institutions to general education schools (i.e. facilitates difficulties of changing institutions and adaptation) (average rank of gymnasium teachers - 43.00, of progymnasium teachers - 31.16), would like to teach in a team that would work according to the model, which corresponds to the needs of educating pupils with disabilities in general education classrooms (average ranks are 45.63 and 28.61 respectively) and team training, i.e. a pair of a general education teacher and a special education teacher in the same classroom is beneficial to all pupils (average ranks are 42,04 and 32,09 respectively). Progymnasium teachers more than gymnasium teachers agree that pupils with disabilities should not be taught in conventional classrooms with pupils with no disabilities, as their teaching process would require too much time of teachers (average rank of progymnasium teachers is 46.61, of gymnasium teachers 27.13) and the responsibility for the education of pupils with disabilities should be shared between the general education teacher and a special education teacher in the same classroom (average ranks are 42.72 and 31.13 respectively). 
SOCIETY. INTEGRATION. EDUCATION

Proceedings of the International Scientific Conference. Volume II, May $25^{\text {th }}-26^{\text {th }}$, 2018. 39-53

Table 2 Difference between the attitudes of the instructor and the gymnasium to inclusive education

\begin{tabular}{|c|c|c|c|c|}
\hline Proposition & School type & $\begin{array}{l}\text { Average } \\
\text { ranks }\end{array}$ & $\begin{array}{l}\text { Mann- } \\
\text { Whitney } \\
\text { U }\end{array}$ & $\mathbf{p}$ \\
\hline \multirow{2}{*}{$\begin{array}{l}\text { Inclusion is a more efficient model for } \\
\text { educating students with mild to moderate } \\
\text { disabilities because it reduces transition } \\
\text { time (i.e., the time required to move from } \\
\text { one setting to another). }\end{array}$} & Progymnasium & 31,16 & \multirow[t]{2}{*}{450,000} & \multirow[t]{2}{*}{0,008} \\
\hline & Gymnasium & 43,00 & & \\
\hline \multirow{2}{*}{$\begin{array}{l}\text { Students with mild to moderate disabilities } \\
\text { should not be taught in regular classes with } \\
\text { non-disabled students because they will } \\
\text { require too much of the teacher's time. }\end{array}$} & Progymnasium & 46,61 & \multirow[t]{2}{*}{310,500} & \multirow[t]{2}{*}{0,000} \\
\hline & Gymnasium & 27,13 & & \\
\hline \multirow[b]{2}{*}{$\begin{array}{l}\text { I would welcome the opportunity to } \\
\text { participate in a consultant teacher model } \\
\text { (i.e., regular collaborative meetings } \\
\text { between special and general education } \\
\text { teachers to share ideas, methods, and } \\
\text { materials) as a means of addressing the } \\
\text { needs of students with mild/moderate } \\
\text { disabilities in regular classrooms. }\end{array}$} & Progymnasium & 28,61 & \multirow[t]{2}{*}{355,500} & \multirow[t]{2}{*}{0,000} \\
\hline & Gymnasium & 45,63 & & \\
\hline \multirow{2}{*}{$\begin{array}{l}\text { All students benefit from team teaching: } \\
\text { that is, the pairing of a general and a } \\
\text { special education teacher in the same } \\
\text { classroom. }\end{array}$} & Progymnasium & 32,09 & \multirow[t]{2}{*}{484,500} & \multirow[t]{2}{*}{0,038} \\
\hline & Gymnasium & 42,04 & & \\
\hline \multirow{2}{*}{$\begin{array}{l}\text { The responsibility for educating students } \\
\text { with mild/moderate disabilities in regular } \\
\text { classrooms should be shared between } \\
\text { general and special education teachers. }\end{array}$} & Progymnasium & 42,72 & \multirow[t]{2}{*}{454,500} & \multirow[t]{2}{*}{0,016} \\
\hline & Gymnasium & 31,13 & & \\
\hline
\end{tabular}

The Kruskal-Wallis criterion was applied to determine the different attitudes of teachers of the 3 age groups towards inclusive education. A statistically significant difference in the attitudes was found only for one statement $\left(\chi^{2}=9.469, \mathrm{df}=2, \mathrm{p}=0.009\right.$ ). 36-46 year-old teachers (average rank is 62.09) compared to 26-35 year-old (average rank is 55.42) and teachers over 47 years old (average rank is 40.65) agree more that in order to satisfy the educational needs of pupils with disabilities, they should be taught in specialized schools.

In order to determine whether there is a difference between how the teachers of the research assess the fact that classrooms for pupils with disabilities should be closed and how pupils with disabilities should be taught in a general education school under the same conditions with peers with no disabilities, a Wilcoxon criterion was applied. 
Baranauskienè \& Saveikienè, 2018. Pursuit of Inclusive Education: Inclusion of Teachers in Inclusive Education

It was possible to identify only 15 cases when teachers we likely to agree on the fact that classrooms for pupils with disabilities should be closed, and 78 cases when teachers were less supportive of the fact that pupils with disabilities should be taught in a general education school under the same conditions with peers with no disabilities $(\mathrm{Z}=-6.515, \mathrm{p}=0.000)$.

The Friedman criterion was applied in order to determine whether teachers' attitudes to some statements related to inclusive education of pupils were different. Teachers of the research are more likely to agree that all school classrooms should be reorganized to meet the needs of pupils with disabilities (average rank is 3.28), but agree less on the fact that in order to satisfy the educational needs of pupils with disabilities, they should be taught in specialized schools (average rank is 2.82), pupils with disabilities should be taught in general education schools under the same conditions with peers with no disabilities (average rank is 2.50), and at least support the fact that classes designed for pupils with disabilities should be closed (average rank is 1.40). The following difference is statistically significant $\left(\chi^{2}=135.344, \mathrm{df}=3, \mathrm{p}=0.000\right)$.

One-factor dispersion analysis (ANOVA) was applied in order to determine whether there is a difference in the indicators of the gymnasium, progymnasium and primary school teachers' "Teachers' attitude towards inclusive education" scale. Levene statistics showed that dispersions of variables are approximately equal $(\mathrm{p}=0.251>0.05)$. Results of the research revealed that indicators of the “Teachers' attitude towards inclusive education" scale do not differ in accordance with the type of school $(\mathrm{F}=1.010, \mathrm{p}=0.368)$. The average score of the primary school teachers' "Teachers' attitude towards inclusive education" scale is slightly higher (5.51) than of progymnasium (5.50) and gymnasium teachers (5.40), but the following difference is not statistically significant.

During the factorial analysis, it was sought to obtain one or a number of summarised variables from several or a dozen of variables of the "Teachers' attitude towards inclusive education” scale similar in their meaning.

Standard deviations of variables are analysed in the Descriptive Statistics table. Several variables with small standard deviations (less than 1) have been found, i.e. hardly varying, relatively non-informative and useless in factor analysis.

KMO measure presented in the KMO and Bartlett's Test table (KaiserMeyer-Olkin Measure of Sampling Adequacy) is fairly good, equals to 0.549 (value of criterion must be $>0.5$ ). The significance level of the Bartlett's sphericity criterion is less than $0.01(\mathrm{p}=0.000)$ and shows that the correlation matrix is statistically significantly different from the unit matrix, variables are correlated. Data for the factorial analysis is appropriate. 
SOCIETY. INTEGRATION. EDUCATION

Proceedings of the International Scientific Conference. Volume II, May $25^{\text {th }}-26^{\text {th }}$, 2018. 39-53

Table 3 Descriptive Statistics: Standard deviations of variables

\begin{tabular}{|c|c|c|c|}
\hline Proposition & Mean & $\begin{array}{l}\text { Std. } \\
\text { Deviation }\end{array}$ & $\begin{array}{l}\text { Analysis } \\
\mathbf{N}\end{array}$ \\
\hline $\begin{array}{l}\text { 1. All students with mild to moderate disabilities should be } \\
\text { educated in regular classrooms with non-handicapped peers to } \\
\text { the fullest extent possible. }\end{array}$ & 4,66 & 1,634 & 105 \\
\hline $\begin{array}{l}\text { 2. It is seldom necessary to remove students with mild to } \\
\text { moderate disabilities from regular classrooms in order to meet } \\
\text { their educational needs. }\end{array}$ & 5,03 & 1,383 & 105 \\
\hline $\begin{array}{l}\text { 3. Most or all separate classrooms that exclusively serve students } \\
\text { with mild to moderate disabilities should be eliminated. }\end{array}$ & 2,69 & 1,281 & 105 \\
\hline $\begin{array}{l}\text { 4. Most or all regular classrooms can be modified to meet the } \\
\text { needs of students with mild to moderate mild to moderate } \\
\text { disabilities. }\end{array}$ & 5,74 & 1,169 & 105 \\
\hline $\begin{array}{l}\text { 5. Students with mil d to moderate disabilities can be more } \\
\text { effectively educated in regular classrooms as opposed to special } \\
\text { education classrooms. }\end{array}$ & 4,02 & 1,995 & 105 \\
\hline $\begin{array}{l}\text { 6. Inclusion is a more efficient model for educating students with } \\
\text { mild to moderate disabilities because it reduces transition time } \\
\text { (i.e., the time required to move from one setting to another). }\end{array}$ & 6,23 & ,750 & 105 \\
\hline $\begin{array}{l}\text { 7. Students with mild to moderate disabilities should not be } \\
\text { taught in regular classes with non-disabled students because they } \\
\text { will require too much of the teacher's time. }\end{array}$ & 6,26 & ,747 & 105 \\
\hline $\begin{array}{l}\text { 8. I have doubts about the effectiveness of including students } \\
\text { with mild/moderate disabilities in regular classrooms because } \\
\text { they often lack the academic skills necessary for success. }\end{array}$ & 6,50 & 1,287 & 105 \\
\hline $\begin{array}{l}\text { 9. I have doubts about the effectiveness of including students } \\
\text { with mild/moderate disabilities in regular classrooms because } \\
\text { they often lack the social skills necessary for success. }\end{array}$ & 5,60 & 1,229 & 105 \\
\hline $\begin{array}{l}\text { 10. I find that general education teachers often do not succeed } \\
\text { with students with mild to moderate disabilities, even when they } \\
\text { try their best. }\end{array}$ & 5,81 & ,867 & 105 \\
\hline $\begin{array}{l}\text { 11. I would welcome the opportunity to team teach as a model } \\
\text { for meeting the needs of students with mild/moderate disabilities } \\
\text { in regular classrooms. }\end{array}$ & 6,32 & 946 & 105 \\
\hline $\begin{array}{l}\text { 12. All students benefit from team teaching: that is, the pairing } \\
\text { of a general and a special education teacher in the same } \\
\text { classroom. }\end{array}$ & 5,67 & 1,222 & 105 \\
\hline $\begin{array}{l}\text { 13. The responsibility for educating students with mild/moderate } \\
\text { disabilities in regular classrooms should be shared between } \\
\text { general and special education teachers. }\end{array}$ & 5,53 & 1,209 & 105 \\
\hline $\begin{array}{l}\text { 14. I would welcome the opportunity to participate in a } \\
\text { consultant teacher model (i.e., regular collaborative meetings } \\
\text { between special and general education teachers to share ideas, } \\
\text { methods, and materials) as a means of addressing the needs of } \\
\text { students with mild/moderate disabilities in regular classrooms. }\end{array}$ & 6,50 & ,502 & 105 \\
\hline
\end{tabular}


Baranauskiene \& Saveikiene, 2018. Pursuit of Inclusive Education: Inclusion of Teachers in Inclusive Education

Table 4 Descriptive Statistics

\begin{tabular}{|c|c|}
\hline Proposition & Extraction \\
\hline $\begin{array}{l}\text { 1. All students with mild to moderate disabilities should be educated in regular, } \\
\text { classrooms with non-handicapped peers to the fullest extent possible. }\end{array}$ & ,473 \\
\hline $\begin{array}{l}\text { 2. It is seldom necessary to remove students with mild to moderate disabilities, } \\
\text { from regular classrooms in order to meet their educational needs. }\end{array}$ & ,605 \\
\hline $\begin{array}{l}\text { 3. Most or all separate classrooms that exclusively serve students with mild to, } \\
\text { moderate disabilities should be eliminated. }\end{array}$ & ,682 \\
\hline $\begin{array}{l}\text { 4. Most or all regular classrooms can be modified to meet the needs of students, } \\
\text { with mild to moderate mild to moderate disabilities. }\end{array}$ & 452 \\
\hline $\begin{array}{l}\text { 5. Students with mil d to moderate disabilities can be more effectively educated in, } \\
\text { regular classrooms as opposed to special education classrooms. }\end{array}$ & 622 \\
\hline $\begin{array}{l}\text { 6. Inclusion is a more efficient model for educating students with mild to moderate, } \\
\text { disabilities because it reduces transition time (i.e., the time required to move from } \\
\text { one setting to another). }\end{array}$ & 527 \\
\hline $\begin{array}{l}\text { 7. Students with mild to moderate disabilities should not be taught in regular, } \\
\text { classes with non-disabled students because they will require too much of the } \\
\text { teacher's time. }\end{array}$ & ,488 \\
\hline $\begin{array}{l}\text { 8. I have doubts about the effectiveness of including students with mild/moderate, } \\
\text { disabilities in regular classrooms because they often lack the academic skills } \\
\text { necessary for success. }\end{array}$ & ,685 \\
\hline $\begin{array}{l}\text { 9. I have doubts about the effectiveness of including students with mild/moderate, } \\
\text { disabilities in regular classrooms because they often lack the social skills necessary } \\
\text { for success. }\end{array}$ & 849 \\
\hline $\begin{array}{l}\text { 10. I find that general education teachers often do not succeed with students with, } \\
\text { mild to moderate disabilities, even when they try their best. }\end{array}$ & ,797 \\
\hline $\begin{array}{l}\text { 11. I would welcome the opportunity to team teach as a model for meeting the, } \\
\text { needs of students with mild/moderate disabilities in regular classrooms. }\end{array}$ & ,606 \\
\hline $\begin{array}{l}\text { 12. All students benefit from team teaching: that is, the pairing of a general and a, } \\
\text { special education teacher in the same classroom. }\end{array}$ & 578 \\
\hline $\begin{array}{l}\text { 13. The responsibility for educating students with mild/moderate disabilities in, } \\
\text { regular classrooms should be shared between general and special education } \\
\text { teachers. }\end{array}$ & 504 \\
\hline $\begin{array}{l}\text { 14. I would welcome the opportunity to participate in a consultant teacher model, } \\
\text { (i.e., regular collaborative meetings between special and general education } \\
\text { teachers to share ideas, methods, and materials) as a means of addressing the needs } \\
\text { of students with mild/moderate disabilities in regular classrooms. }\end{array}$ & 463 \\
\hline
\end{tabular}

Table Communalities (Table 4.) reveals that variables are related to the extracted factors. Commonalities of all variables after extraction (in the column Extraction) exceed 0.2. The following indicates that there are no variables that have a particularly weak relation to the factors obtained. I have doubts about the effectiveness of including students with mild/moderate disabilities in regular classrooms because they often lack the social skills necessary for success and I 
find that general education teachers often do not succeed with students with mild to moderate disabilities, even when they try their best has the most correlation with all extracted factors, I would welcome the opportunity to participate in a consultant teacher model (i.e., regular collaborative meetings between special and general education teachers to share ideas, methods, and materials) as a means of addressing the needs of students with mild/moderate disabilities in regular classrooms has the weakest correlation.

Initial true values of all 5 factors are greater than 1, but only the first of them is strong, its true value equals to 2.693 and the following factor explains about 19 per cent of the general dispersion of variables. After turning, the first factor explains 18.462 per cent of the general dispersion of variables, second - 10.965 per cent, third -10.837 per cent, fourth -10.268 per cent, and the fifth one -8.961 per cent. All 5 extracted factors together explain 59.5 per cent of dispersion.

Table 5 Total Variance Explained

\begin{tabular}{|l|r|r|r|r|r|r|}
\hline \multirow{2}{*}{ Component } & \multicolumn{7}{|c|}{$\begin{array}{c}\text { Extraction Sums of Squared } \\
\text { Loadings }\end{array}$} & \multicolumn{3}{c|}{ Rotation Sums of Squared Loadings } \\
\cline { 2 - 7 } & Total & $\begin{array}{c}\text { \% of } \\
\text { Variance }\end{array}$ & $\begin{array}{c}\text { Cumulative } \\
\text { \% }\end{array}$ & Total & $\begin{array}{c}\text { \% of } \\
\text { Variance }\end{array}$ & $\begin{array}{c}\text { Cumulative } \\
\text { \% }\end{array}$ \\
\hline 1 & 2,693 & 19,236 & 19,236 & 2,585 & 18,462 & 18,462 \\
\hline 2 & 1,633 & 11,668 & 30,904 & 1,535 & 10,965 & 29,428 \\
\hline 3 & 1,487 & 10,622 & 41,526 & 1,517 & 10,837 & 40,264 \\
\hline 4 & 1,312 & 9,373 & 50,899 & 1,438 & 10,268 & 50,533 \\
\hline 5 & 1,203 & 8,595 & 59,493 & 1,254 & 8,961 & 59,493 \\
\hline Extraction Method: Principal Component Analysis. \\
\hline \multicolumn{7}{|l|}{} \\
\hline
\end{tabular}

The Rotated Component Matrix table presents that the following corresponds to factor I - I have doubts about the effectiveness of including students with mild/moderate disabilities in regular classrooms because they often lack the academic skills necessary for success; I have doubts about the effectiveness of including students with mild/moderate disabilities in regular classrooms because they often lack the social skills necessary for success; I find that general education teachers often do not succeed with students with mild to moderate disabilities, even when they try their best. The following factor can be called "Doubts about the efficiency of inclusive education"

Corresponds to factor II - Students with mil d to moderate disabilities can be more effectively educated in regular classrooms as opposed to special education classrooms; Inclusion is a more efficient model for educating students with mild to moderate disabilities because it reduces transition time (i.e., the time required to move from one setting to another); Students with mild to moderate disabilities should not be taught in regular classes with non-disabled students 
Baranauskiene \& Saveikiene, 2018. Pursuit of Inclusive Education: Inclusion of Teachers in Inclusive Education

because they will require too much of the teacher's time; I would welcome the opportunity to participate in a consultant teacher model (i.e., regular collaborative meetings between special and general education teachers to share ideas, methods, and materials) as a means of addressing the needs of students with mild/moderate disabilities in regular classrooms. The following factor can be called "Teachers' attitudes towards education of pupils with disabilities in general education schools".

Corresponds to factor III - Most or all separate classrooms that exclusively serve students with mild to moderate disabilities shoul be eliminated; Most or all regular classrooms can be modified to meet the needs of students with mild to moderate mild to moderate disabilities. The following factor can be called "Teachers' attitudes towards the conversion of classrooms for education of pupils with disabilities".

Corresponds to factor IV - All students benefit from team teaching: that is, the pairing of a general and a special education teacher in the same classroom; The responsibility for educating students with mild/moderate disabilities in regular classrooms should be shared between general and special education teachers; I would welcome the opportunity to participate in a consultant teacher model (i.e., regular collaborative meetings between special and general education teachers to share ideas, methods, and materials) as a means of addressing the needs of students with mild/moderate disabilities in regular classrooms. The following factor can be called "Teachers' attitudes towards the need for help".

Corresponds to factor $\mathbf{V}$ - All students with mild to moderate disabilities should be educated in regular classrooms with non-handicapped peers to the fullest extent possible; It is seldom necessary to remove students with mild to moderate disabilities from regular classrooms in order to meet their educational needs. The following factor can be called 'Teachers' attitudes towards education of pupils with disabilities".

Pearson correlation coefficient was applied to determine whether there is a relationship between the age of teachers of the research and the extracted factors. Statistically significant relationships were established only in the group of gymnasium teachers. The inverse average relationship was established between the I factor "Doubts about the efficiency of inclusive education" and the age of gymnasium teachers $(\mathrm{r}=-0.394, \mathrm{p}=0.017)$. The following reveals that indicators of this factor for older teachers are decreasing. Moreover, average, but positive relationship was established between the III factor “Teachers' attitudes towards the conversion of classrooms for education of pupils with disabilities" and the age of gymnasium teachers $(\mathrm{r}=0.405, \mathrm{p}=0.014)$. The following reveals that indicators of this factor for older teachers are increasing. 
In order to establish the relationship between the scale of "Teachers' attitude towards inclusive education" and the age of teachers, a simple linear regression was performed. The symmetry of the distinctive indicators of the "Teachers' attitude towards inclusive education" scale was tested first.

ANOVA table shows that the model of regression is statistically reliable (Sig. p.0.035, $\mathrm{p}<0.05$ ). Accordingly, the regression equation makes sense. Assessment of the "Teachers' attitude towards inclusive education" scale depends on the age of teachers.

Table 6 ANOVA

\begin{tabular}{|l|l|r|r|r|r|r|}
\hline \multicolumn{2}{|l|}{ Model } & \multicolumn{1}{c|}{$\begin{array}{c}\text { Sum of } \\
\text { Squares }\end{array}$} & df & Mean Square & F & \multicolumn{1}{c|}{ Sig. } \\
\hline \multirow{3}{*}{1} & Regression &, 521 & 1 &, 521 & 4,567 &, $035^{b}$ \\
\cline { 2 - 7 } & Residual & 11,744 & 103 &, 114 & & \\
\cline { 2 - 8 } & Total & 12,265 & 104 & & & \\
\hline
\end{tabular}

However, the following relationship is very weak. The column Adjusted $R$ Square (0.033) in the Model Summary table shows that only about 3 per cent of variations of the "Teachers' attitude towards inclusive education" scale assessments depends on the age of teachers.

Table 7 Model Summary

\begin{tabular}{|r|r|r|r|}
\hline $\mathrm{R}$ & R Square & \multicolumn{1}{|c|}{$\begin{array}{c}\text { Adjusted R } \\
\text { Square }\end{array}$} & $\begin{array}{c}\text { Std. Error of the } \\
\text { Estimate }\end{array}$ \\
\hline, $206^{\mathrm{a}}$ &, 042 &, 033 &, 33766 \\
\hline
\end{tabular}

A regression equation can be made. According to the data presented in the Coefficients table: assessment of the "Teachers' attitude towards inclusive education" scale $=5,772-0,007^{*}$ age. The following means that the assessment of the "Teachers' attitude towards inclusive education" scale is 5.772, then the assessment decreases by 0.007 points with each year of the teachers' age.

Table 8 Coefficients

\begin{tabular}{|c|c|c|c|c|c|c|}
\hline \multirow{2}{*}{\multicolumn{2}{|c|}{ Model }} & \multicolumn{2}{|c|}{ Unstandardized Coefficients } & \multirow{2}{*}{$\begin{array}{c}\text { Standardized } \\
\text { Coefficients }\end{array}$} & \multirow[t]{2}{*}{$\mathrm{t}$} & \multirow[t]{2}{*}{ Sig. } \\
\hline & & $\mathrm{B}$ & Std. Error & & & \\
\hline \multirow{2}{*}{1} & (Constant) & 5,772 & 146 & & 39,645 & 000 \\
\hline & 1. Age &,- 007 & ,003 &,- 206 & $-2,137$ & ,035 \\
\hline
\end{tabular}


Baranauskienè \& Saveikienè, 2018. Pursuit of Inclusive Education: Inclusion of Teachers in Inclusive Education

For the avoidance of doubts, the Spearman's rank correlation coefficient was applied to calculate the relationship between the indicators of the "Teachers' attitude towards inclusive education" scale and the age of teachers. An inverse weak and statistically significant relationship (Spearman's rho $=-0.243, p=0.013$ ) was determined. The following shows that with the increase of the age of teachers, indicators of the "Teachers' attitude towards inclusive education" scale decrease.

\section{Conclusions}

A study has been conducted demonstrating that the attitudes of educators participating in the study to inclusive education of pupils with a disability are basically positive.

Teachers who participated in the study agree that all school classes need to be rebuilt to meet the needs of students with disabilities, and students with disabilities should be taught in a general education school in an equal educational environment with peers without disabilities.

The differences between the attitude of teachers to the model of inclusive education and the type of the pedagogical school were statistically significant.

More than just a gymnasium teacher, either a progimist or an elementary school teacher, fully agrees that a model of inclusive education provides a more efficient transition of students with disabilities from special education to general education schools.

It was found that the assessment of The Teachers' Attitudes Toward Inclusion Scale (TATIS) depends on the age of the teachers. As the age of teachers grows, the teacher's attitude towards inclusive education is reduced.

\section{References}

Cullen, J. P., Gregory, J. L., \& Noto, L. A. (2010). The Teacher Attitudes Toward Inclusion Scale (TATIS) Technical Report; Online Submission, Retrieved from https://eric.ed.gov/?id=ED509930

Florian, L. (2015). Inclusive Pedagogy: A Transformative Approach to Individual Differences but Can It Help Reduce Educational Inequalities?”Scottish Educational Review, 47 (1), 5-14.

Kozleski, E. B., \& Yu, I. (2016). Inclusive Education. New York: Oxford University Press.

Kozleski, E. B., \& Thorius, K. (2014) Ability, Equity, and Culture: Sustaining Inclusive Urban Education Reform. New York: Teachers College Press.

Norwich, B., \& Koutsouris, G. (2017). Addressing Dilemmas and Tensions in Inclusive Education; Education, Change, and Development. Retrieved from http://education.oxfordre.com/view/10.1093/acrefore/9780190264093.001.0001/acrefor e-9780190264093-e-154 
Proceedings of the International Scientific Conference. Volume II, May $25^{\text {th }}-26^{\text {th }}$, 2018. 39-53

Rakap, S., Cig, O., \& Parlak-Rakap, A. (2017). Preparing preschool teacher candidates for inclusion: impact of two special education courses on their perspectives, Journal of Research in Special Educational Needs, 17, 77-151.

Sailor, W. (2016). Equity as a Basis for Inclusive Educational Systems Change, Australasian Journal of Special Education, 41, 1-17.

Stepaniuk, I. (2018). Inclusive education in Eastern European countries: a current state and future directions, International Journal of Inclusive Education, Retrieved from https://www.tandfonline.com/doi/abs/10.1080/13603116.2018.1430180

UNESCO (1994). The Salamanca Statement and Framework for Action on Special Needs Education. Retrieved from http://www.unesco.org/education/pdf/SALAMA_E.PD 